О Р И Г Н А Л В О Е И С С Л Д О В А Н И Е

\title{
Сравнительный анализ многолетней динамики развития основных болезней винограда в условиях Крыма
}

Евгения Спиридоновна Галкина, канд. с.-х. наук, вед. науч. сотр. лаборатории защиты растений, galkinavine@mail.ru; Наталья Васильевна Алейникова, д-р с.-х. наук, заведующая лабораторией защиты растений, aleynikova@magarach-institut.ru

Федеральное государственное бюджетное учреждение науки «Всероссийский национальный научно-исследовательский институт виноградарства и виноделия «Магарач» РАН», 298600, Россия, Республика Крым, г. Ялта, ул. Кирова, 31

С целью моделирования будущих сценариев развития милдью и оидиума винограда в условиях изменения климата установлены основные закономерности сезонной и многолетней (1987-2018 гг.) динамики развития данных заболеваний на виноградниках Крыма. Многолетняя динамика милдью в ампелоценозах Югозападной зоны виноградарства свидетельствует о непрерывности и неравномерности развития болезни по годам с высокой зависимостью $(\mathrm{r}=0,73-0,8)$ от количества осадков в период с мая по август. Оидиум на виноградниках Южного берега Крыма развивается непрерывно, относительно постоянно и в средней степени зависит от относительной влажности воздуха в мае $(r=0,52)$. Сезонные динамики эпифитотического процесса милдью определяются гидротермическими условиями и сильно варьируют по годам; для оидиума установлено относительное постоянство данного процесса и смещение начала развития болезни на более ранние сроки, что обусловлено климатическими изменениями.

Ключевые слова: виноград; милдью; оидиум; сезонная; многолетняя динамика; прогноз развития; урожай; климат.
O R I G I N A L R E S E A C H

\section{Comparative analysis of the multi-year evolution of the principal vine diseases in Crimea}

Yevgenia Spiridonovna Galkina, Natalia Vasilievna Aleinikova

Federal State Budget Scientific Institution All-Russian National Research Institute of Viticulture and Winemaking Magarach of the RAS, Kirova Str. 31, Yalta 298600 Russian Federation

To simulate future scenarios of mildew and oidium progression on vines in a changing climate, major patterns have been established for seasonal and longterm (1987-2018) dynamics of the diseases in the vineyards of Crimea. The multi-year mildew dynamics in the ampelocenoses of the southwestern viticultural zone demonstrate continuity and uneven progression of the disease by years with a high rainfall dependence $(r=0.73-0.8)$ between May and August. Oidium in the vineyards of the South Coast has been evolving continuously and relatively constantly; it moderately depends on relative air humidity in May $(r=0.52)$. The seasonal dynamics of the epiphytotic mildew process is governed by hydrothermal conditions, and vary greatly by years; for oidium, a relative continuity of the process and a shift in the onset of the disease to earlier periods were established, which is caused by climate change.

Key words: grapevine; mildew; oidium; seasonal, long-term dynamics; development forecast; the crop; climate.

\footnotetext{
Как цитировать эту статью:

\section{How to cite this article} Russian)

УДК: 634.8.047:632.3/.7

Поступила 19.06.2019

Принята к публикации 20.08.2019

(C) Авторы, 2019
}

Галкина Е.С., Алейникова Н.В. Сравнительный анализ многолетней динамики развития основных болезней винограда в условиях Крыма // «Магарач». Виноградарство и виноделие, 2019; 21(3); C. 244-249. DOI 10.35547/IM.2019.21.3.011

Galkina Y.S. Aleinikova N.V. Comparative analysis of the long-term dynamics of the development of the main diseases of grapes in the conditions of Crimea. Magarach. Vinogradarstvo i vinodelie = Magarach. Viticulture and Winemaking, 2019; 21(3):244-249. DOI 10.35547/IM.2019.21.3.011 (in 
$\mathrm{B}$ ведение. Основными вызовами современного виноградарства в мире являются глобальное изменение кмимата, с участившимися погодными стрессами; неадаптированность и некачественное применение технологий защиты; снижение негативного возАействия на окружающую среay $[1,2]$.

Согласно прогнозам ООН, повышение температуры воздуха на планете в XXI столетии может составить $1,5-4^{\circ} \mathrm{C}$. Аля Крыма выявлена стойкая тенАенция к повышению среднегодовой температуры воздуха, сумма активных температур выше $10^{\circ} \mathrm{C}$ за проанализированный период (33 года), увеличимась на $567^{\circ} \mathrm{C}[1,3]$. На Южном берегу Крыма в XXI веке установлено УАлинение продолжительности самой тепмой части кетнего периода с температурами выше $20^{\circ} \mathrm{C}$ за счет более раннего их наступления и позАнего окончания, а также увеличение числа аномально жарких Аней в 2,5-3 раза [4].

Поскольку кАимат явАяется кАючевой Авижущей симой агроэкосистемы, его изменение сказывается на развитии сельскохозяйственных культур и вреАящих им организмов. Аля кажАой патологической системы должны быть определены последствия изменения көимата $[1,5,6]$.

ААаптация защиты растений преАполагает использование среАств, методов и технологий, оптимальных Аля агрокмиматических регионов, сортов, способов их возделывания, метеоусмовий и т.А., обеспечивающих получение высоких, стабильных, экономически оправданных урожаев [7].

На виноградных насаждениях Крыма основное значение в комплексе болезней, которые вызывают серьезные потери и ухудшение качества урожая винограда, принадлежит эпифитотийным заболеваниям: милдью (Plasmopara viticola Berl. et Toni) и оидиуму (Uncinula necator Berkl.) [8-13]. В настоящее время вопросы влияния различных факторов на развитие мицАью и оидиума винограда по-прежнему явмяются актуацьными, о чём свидетельствуют многочисленные научные публикации, в т.ч. зарубежные [14-20].

В связи с прогнозируемым изменением кмимата появицась необходимость проведения исследований по моделированию риска развития основных болезней винограда, основанному на знании их реакций на основные факторы внешней среды. Погодные усмовия играют важную роль в возникновении и развитии милдью и оидиума винограАа. Контролируя и прогнозируя эти состояния по мере их появления, можно определить периоды заражения и защитить виноградную мозу до наступления заражения $[2,5,6$, 21-24].

Цель настоящих исследований закмючалась в определении основных закономерностей многолетней и сезонной Аинамики развития данных заболеваний на винограАниках Крыма по трем временным периодам: 1987-2003 гг., 2004-2013 гг. и 2014-2018 гг. Аля моделирования будущих сценариев развития милАью и оидиума в условиях изменения кмимата и технологии выращивания винограда

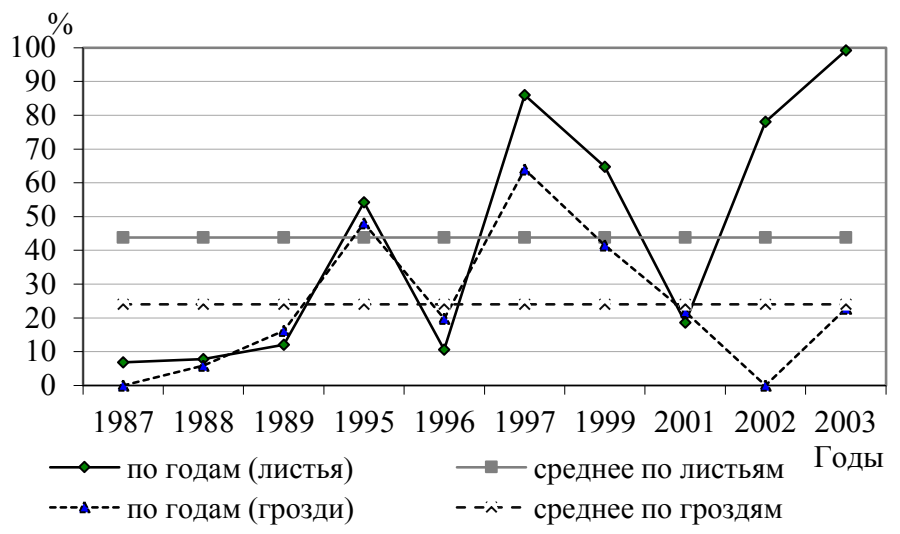

Рис. 1. Многолетняя динамика развития милдью, Юго-западная зона виноградарства Крыма, 1987-2003 гг.

Fig. 1. Multi-year mildew development dynamics, southwestern viticultural zone of Crimea, 1987-2003

\section{Материалы и методы}

Исследования по изучению сезонной и многолетней Аинамики милАью и оидиума с учетом изменений климата в регионе, определению влияния факторов абиотического происхожАения на зональные особенности их развития, проводили на промышленных насажАениях Авух основных зон виноградарства: Южный берег Крыма и Юго-западный Крым. При этом использовались общепринятые в виноградарстве и защите растений методы $[25,26]$. Учеты и наблюдения проводились в условиях естественного инфекционного фона по основным фенологическим фазам развития винограда, при этом опредемяли сроки появления инфекции и Аинамику ее развития. ОАновременно провоАился детальный анализ метеорологических условий, а именно показателей среАнесуточной температуры возАуха, количества осадков и относительной влажности воздуха. В статье использованы материалы докторской Аиссертации Алейниковой Н.В. «Основные болезни винограда в условиях Крыма, прогноз их развития и система защиты» (ЯАта, 2010).

\section{Результаты исследований}

Сравнительный анализ данных многолетней динамики основных болезней винограда мицдью и оидиума в ампемоценозах Крыма проведен по временным периодам: 1987-2003 гг. (1 периоА), 2004-2013 гг. (2 периоА) и 2014-2018 гг. (3 периоА), различающихся по технологии выращивания культуры и погодным условиям.

Анализ многолетней Аинамики мицдью проводицся на виноградниках Юго-западной зоны виноградарства, где скмадываются более бцагоприятные погодные условия Аля развития патогена. В первом анализируе-

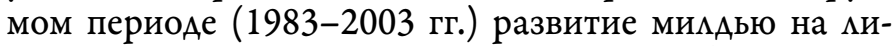
стьях и грозАях очень сильно варьировало (коэффициент вариации 83 и $88 \%$ соответственно), колебание со-

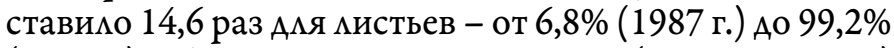
(2003 г.) и 64 раза Аля гроздей - от 0\% (1987 и 2002 гг.) Ао 64\% (1997 г.). За исследуемый период заболевание развивацось три раза по типу эпифитотии: в 1995, 1997 и 2003 годах, причем в последнем только на иистьях. Средние значения развития болезни $43,8 \%$ на Аистьях и $24 \%$ на гроздях характеризовались как эпифитотийное и умеренное (рис.1). 
Второй период (2004-2013 гг.) также характеризовался высокими коэффициентами вариации развития мицдью как на $и$ итьях, так и на грозАях винограда - 88 и $73 \%$ соответственно, колебание

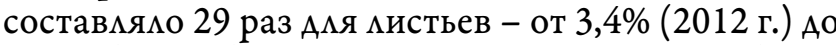
99,1\% (2004 г.) и 64 раза Аля грозАей - от $0 \%(2007$ г.) Ао 64,7\% (2004 г.). Эпифитотию фиксировами только в 2004 году. В целом за десятилетие среАние значения развития мицдью на Аистьях $(37 \%)$ и гроздях $(27,2 \%)$ характеризовались как умеренные (рис. 2).

За третий период (2014-2018 гг.) коэффициенты вариации развития мимдью были ниже, чем в первых

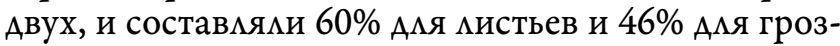
Аей. Максимацьно высокий уровень интенсивности заболевания зафиксирован в 2015 году. В среднем за данный период милдью развивалось умеренно на $\Lambda$ истьях (23\%) и в слабой степени на гроздях (13\%) (рис. 3).

Таким образом, в ампемоценозах Юго-западной зоны виноградарства Крыма развитие мицдью с 1987 года было непрерывным и неравномерным. Многометняя Аинамика заболевания свидетельствует о Аостоверно высокой зависимости $(\mathrm{r}=0,8)$ развития болезни на Аистьях от количества осадков в период с мая по август, что свидетельствует о существенном значении краткосрочного прогноза развития мицАью винограда. В целом за 25 мет наблюдений эпифитотийное развитие заболевания наблюдали через 4-5 Ает, то есть его вероятность составцяет $20 \%$.

Сезонная динамика эпифитотического процесса мицдью в условиях Юго-западного Крыма также определялась гиАротермическими условиями. В связи с этим время проявцения первых визуацьных признаков заболевания очень симьно варьировало по годам проведения исследований (2006-2018 гг.). Так, 4 года из 13 с вероятностью $30 \%$ начало развития заболевания наблюдали в 3-й декаде мая и 3 -й Аекаде июня, 1 раз в 3-й декаде июля и дважды - в 3-й декаде августа (табл. 1).

Анализ многолетней Аинамики оидиума провоАился на виноградниках Южного берега Крыма, гАе практически ежегодно наблюдаются эпифитотии заболевания в связи с благоприятными погоднокАиматическими условиями Аля развития патогена. В первом рассматриваемом периоде (1993-2003 гг.) коэффициенты вариации Аля значения «развитие болезни» на Аистьях (55\%) и гроздях (53\%) были значительно ниже, чем Аця мимдью, колебание дан-

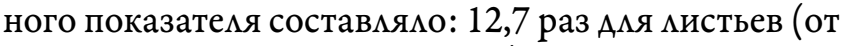
$5,2 \%$ в 2003 г. Ао 66\% в 1994 г.) и 8,8 раз Аля грозАей (от $11,3 \%$ в 2003 до $100 \%$ в 1994 г.). В среднем

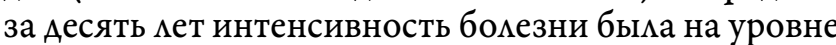

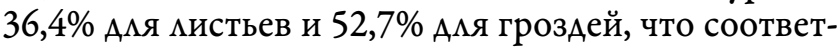
ствует умеренному и эпифитотийному развитию. В слабой степени на $и$ итьях и грозАях винограда оиАиум развивался только в 1993 и 2003 годах (рис. 4).

В следующее десятияетие (2004-2013 гг.) в цемом уровень развития болезни бым выше и характеризовался как эпифитотийный (средние значения - 52 и $82 \%$ Аля Аистьев и гроздей), а коэффициенты

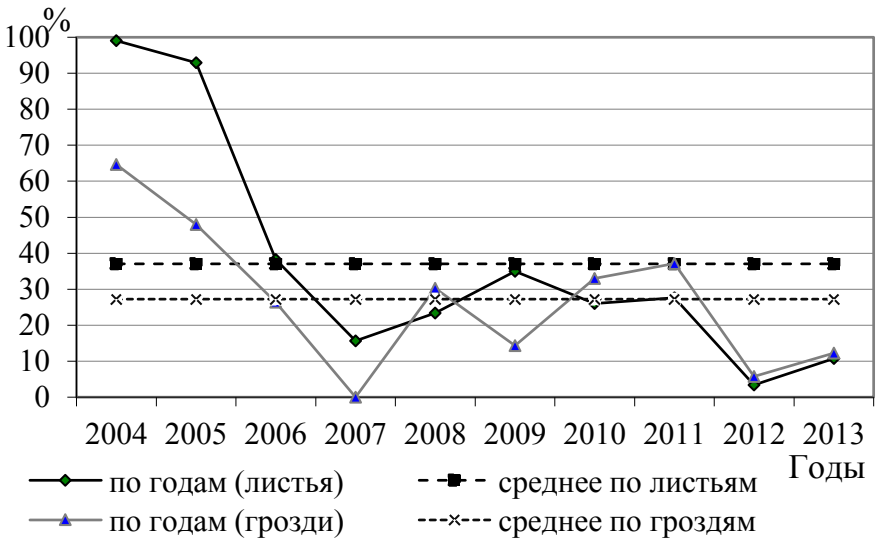

Рис. 2. Многолетняя динамика развития милдью, Юго-западная зона виноградарства Крыма, 2004-2013 гг.

Fig. 2. Multi-year mildew development dynamics, southwestern viticultural zone of Crimea, 2004-2013.

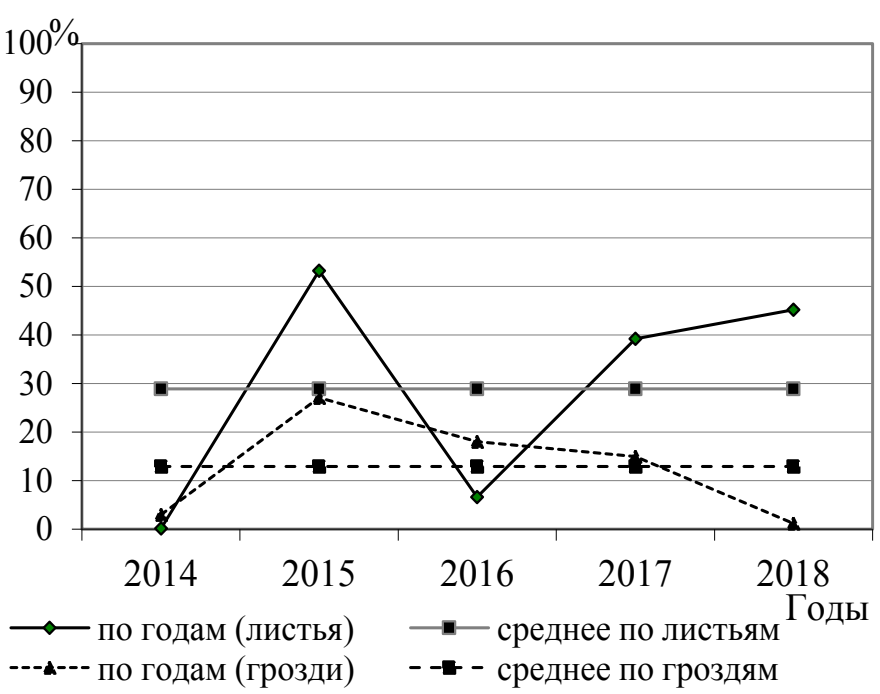

Рис. 3. Многолетняя динамика развития милдью, Юго-западная зона виноградарства Крыма, 2014-2018 гг.

Fig. 3. Multi-year mildew development dynamics, southwestern viticultural zone of Crimea, 2014-2018.

Таблица 1. Сроки первичного проявления милдью в Югозападном Крыму

Table 1. The primary mildew manifestation dates in the southwest Crimea

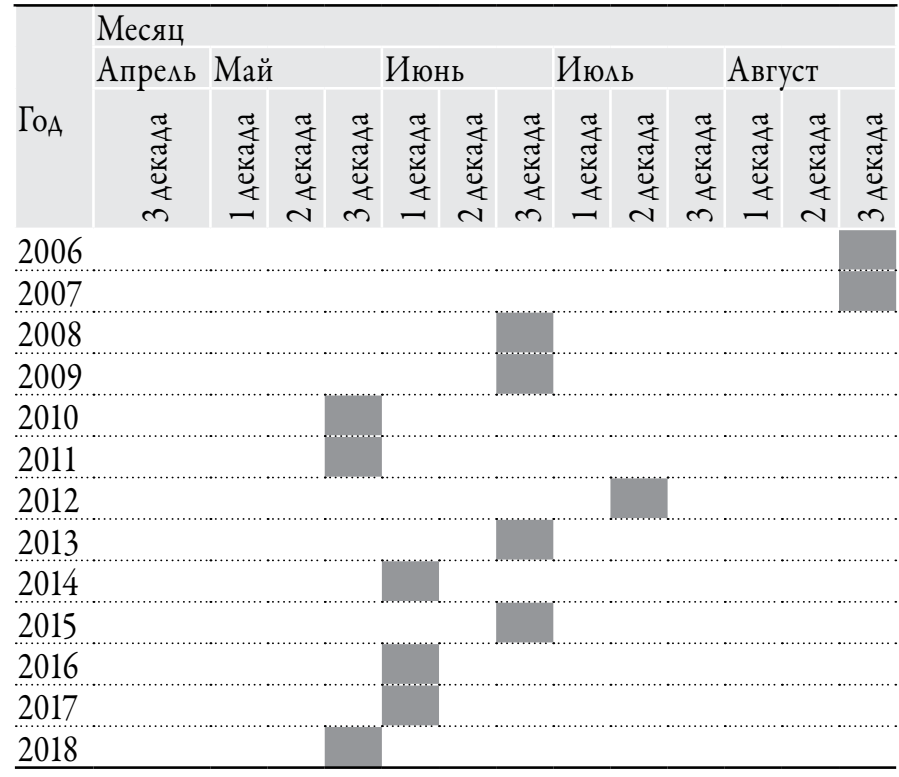




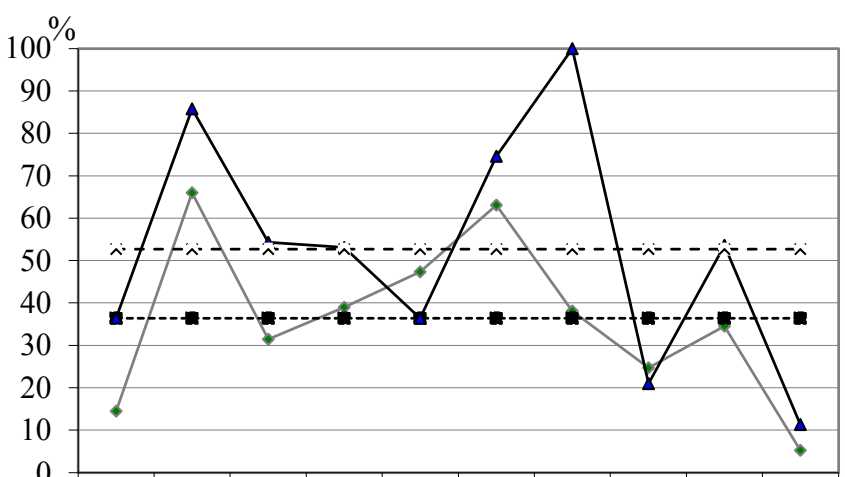

1993199419951996199719981999200120022003

—— по годам (листья) ------ среднее по листьям $\longrightarrow$ по годам (грозди) - - -i- - среднее по гроздям

Рис. 4. Многолетняя динамика развития оидиума, Южный берег Крыма, 1993-2003 гг.

Fig. 4. Multi-year oidium development dynamics, the South Coast of Crimea, 1993-2003

вариации ниже ( 45 и $25 \%$ ), чем в предыдущий периоА. Слабое развитие болезни на Аистьях наблюдали только в 2007 году (по мнению ученых NASA, год признан одним из самых жарких за последнее десятиметие). Комебание развития оидиума также бымо ниже и составицо 7,6 раз Аля Аистьев - от $12,1 \%$ (2007 г.) Ао 91,7\% (2009 г.) и 2,4 раза ААя гроздей - от $42,3 \%$ (2007 г.) до $100 \%$ (2009 г.) (рис. 5).

В период с 2014 по 2018 год значения развития заболевания также варьировали в меньшей степени, чем в первый периоА, коэффициент вариации и ААя $\Lambda$ истьев, и Аля гроздей бым на уровне $30 \%$. Комебание состав яно всего 3 раза Аля Аистьев (от 19,1\% в 2016 г. Ао 56,5\% в 2014 г.), 2 раза Амя гроздей (от 51\% в 2018 г. Ао 100\% в 2017 г.) и было минимальным во все анализируемые периоды. Средние значения развития оидиума на Аистьях (43\%) и грозАях (69\%) соответствовали эпифитотийному уровню (рис. 6).

В целом многолетняя динамика оидиума на виноградных насаждениях Южного берега Крыма свидетельствует о непрерывности и относительном постоянстве интенсивности его развития по годам $(80 \%)$, а также менее значительной зависимости от погодных условий, чем у милАью. В то же время установлена среАняя зависимость $(\mathrm{r}=0,52)$ интенсивности развития оидиума на Аистьях и относительной влажности воздуха в мае. Установленные закономерности свидетельствуют о немаловажном значении обязательного мониторинга и краткосрочного прогноза развития оидиума.

Анализ сезонной Аинамики эпифитотийного процесса оидиума на виноградных насаждениях Южного берега Крыма в 2006-2018 гг. позволяет констатировать ее относительное постоянство и смещение начала развития заболевания на более ранние сроки. Так, если в период с 2006 по 2010 гг. (5 ^ет из 13, вероятность 38,5\%) проявмение первых визуацьных признаков вторичной инфекции фиксировали в третьей декаде мая, то, начиная с 2014 года, Аанное явление наблюдали в первой декаде мая. Установленные особенности обусловлены кмиматическими изменениями и более ранним развитием

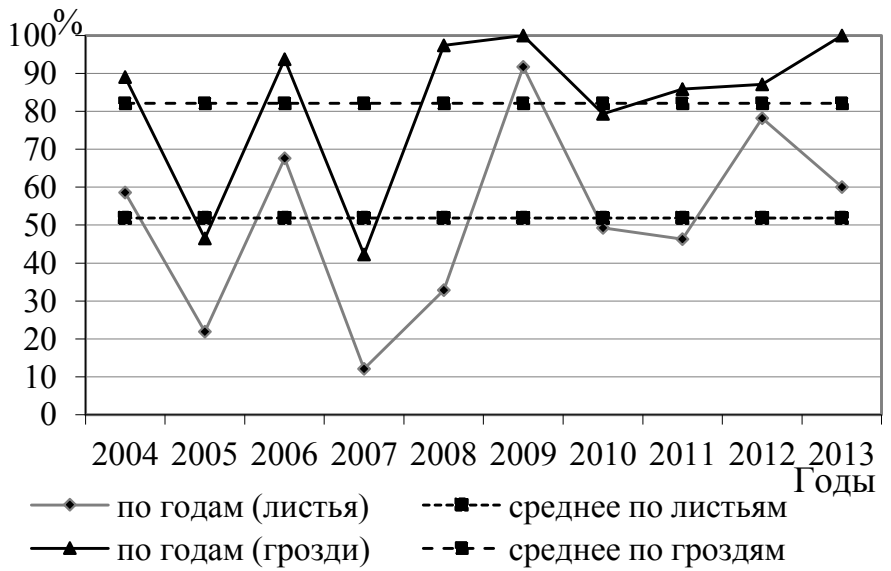

Рис. 5. Многолетняя динамика развития оидиума, Южный берег Крыма, 2004-2013 гг.

Fig. 5. Multi-year oidium development dynamics, the South Coast of Crimea, 1993-2003

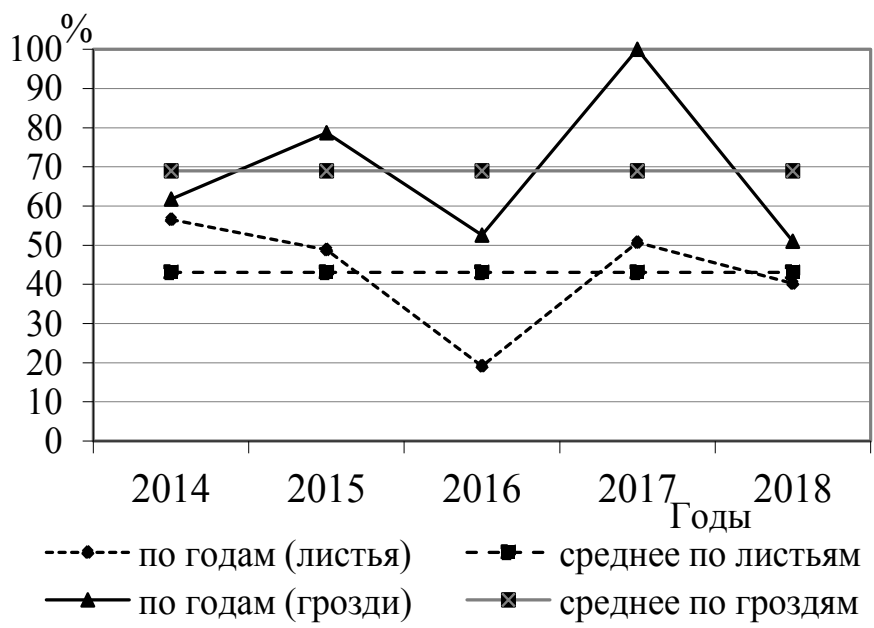

Рис. 6. Многолетняя динамика развития оидиума, Южный берег Крыма, 2014-2018 гг.

Fig. 6. Multi-year oidium development dynamics, the South Coast of Crimea, 1993-2003

Таблица 2. Сроки проявления вторичной инфекции оидиума на Южном берегу Крыма

Table 2. Secondary oidium infection manifestation dates in the South Coast of Crimea

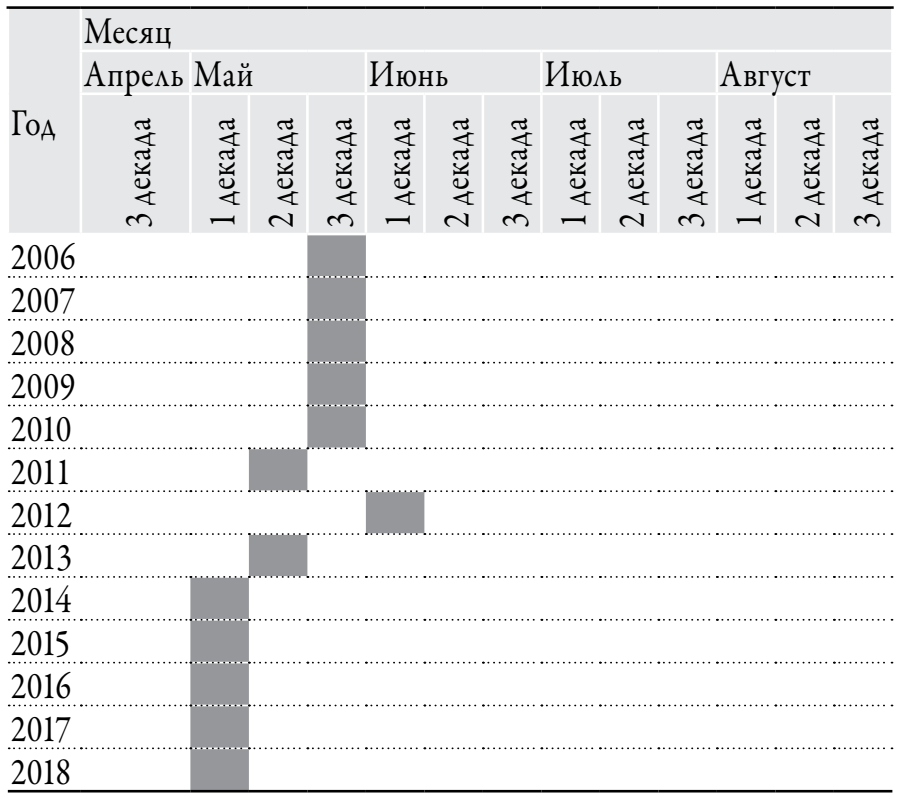


виноградных растений в этот период (табц. 2).

Выводы. Таким образом, установмены основные закономерности сезонной и многолетней (1987-2018 гг.) Аинамики развития мицдью и оидиума винограда в ампелоценозах Крыма. Многолетняя динамика мицдью в ампелоценозах Юго-западной зоны виноградарства свидетемьствует о непрерывности и неравномерности развития по годам со значительной ее зависимостью ( $\mathrm{r}=0,73-0,8)$ от количества осадков в период с мая по август. Оидиум на виноградниках Южного берега развивается непрерывно, относительно постоянно и в средней степени зависит от относитецьной вцажности воздуха в мае $(r=0,52)$. Сезонная динамика эпифитотийного процесса мимАью определяется гиАротермическими условиями и симьно варьирует по годам; Аһя оидиума установцено относитемьное постоянство Аанного процесса и смещение начама развития болезни на более ранние сроки, что обусловцено кмиматическими изменениями.

\section{Источники финансирования}

Статья подготовлена в рамках выполнения ГосуАарственного задания № 0833-2019-0011 (0833-20150007)

\section{Financing source}

The article was written within the framework of the State assignment № 0833-2019-0011 (0833-2015-0007)

\section{Конфликт интересов}

Авторы статьи подтверАили отсутствие конфмикта интересов, о котором необходимо сообщить.

\section{Conflict of interests}

No declared.

\section{Список литературы/References}

1. Санин С. С. Проблемы фитосанитарии России на современном этапе / С. С. Санин // Защита и карантин растений. 2016. - № 4. - C. 3-6.

[Sanin S. S. Problemy fitosanitarii Rossii na sovremennom etape [Challenges of the Russian plant health care at the present stage]. Zashchita i karantin rastenii [Plant Protection and Quarantine]. 2016. - № 4. - P. 3-6. (in Russin)]

2. E3S Web of Conferences 50, 01006 (2018) https://doi. org/10.1051/e3sconf/20185001006 XII CongresoInternacional Terroir (C) The Authors, published by EDP Sciences. This is an open access article distributed under the terms of the Creative Commons Attribution License 4.0 (http://creativecommons. org/licenses/by/4.0/). Climate change and vine protection : the case of mildews management in Burgundy S. Zito1, A. Caffarra2, Y. Richard1 , T. Castel1 , B. Bois1,3 1 CRC - UMR Biogeosciences, Université Bourgogne FrancheComté / CNRS, 6 Bd Gabriel, 21000 Dijon, France 2 ITK, Avenue de l'Europe, 34830 Clapiers 3 InstitutUniversitaire de la Vigne et du Vin, Université Bourgogne FrancheComté, rue Claude Ladrey, 21000 Dijon, France.

3. Рыбалко Е.А. Исследование тенденций изменения климатических условий в Республике Крым для планирования размещения виноградных насаждений / Рыбалко Е.А., Баранова Н.В. // Системы контроля окружающей среды. - 2018. - № 14 (34). - C. 116-121.

[Rybalko Ye.A., Baranova N.V. Issledovaniye tendentsii izmeneniya klimaticheskih uslovii $v$ Respublike Krym dlya planirovaniya razmeshcheniya vinogradnyh nasazhdenii [Trend studies of the changing climate conditions in the Republic of Crimea for the purpose of vineyards planning]. Sistemy kontrolya okruzhayushchei sredy. [Environmental control systems]. 2018.
- № 14 (34). - P. 116-121. (in Russian)]

4. Корсакова С.П. Динамика временных границ климатических сезонов на Южном берегу Крыма в условиях изменения климата / Корсакова С.П., Корсаков П.Б. // Бюллетень ГНБС. - 2018.- Вып. 127. С. - 107-115.

Korsakova S.P., Korsakov P.B. Dinamika vremennyh granits klimaticheskih sezonov na Yuzhnom beregu Kryma v usloviyah izmeneniya klimata [Dynamics of the climatic season timeframes in theSouth Coast of Crimea in a changing climate]. Byulleten' GNBS [GNSS Bulletin]. - 2018. - Is. 127. - P. 107-115. (in Russian)]

5. K.H. Arafat, 2015. Application of Statistical Modelfor Forecasting Powdery Mildew of Grapesunder Egyptian Conditions Based on Meteorological Data. International Journal of Plant Pathology, 6: 48-57. DOI: 10.3923/ ijpp.2015.48.57.

6. F. Salinari, G. Simona, T. Francesco Nicola, R. Andrea, R. Vittorio, S. Federico, R. Cynthia, G. Maria Lodovica, Downy mildew (Plasmoparaviticola) epidemics on grapevine under climate change, Global Change Biology. 12 1299-1307 (2006).

7. Санин, С. С. Адаптивная защита растений - важное звено современного растениеводства / С. С. Санин // Защита и карантин растений. - 2019. - № 2. - С. 3-10.

[Sanin S. S. Adaptivnaya zashchita rastenii - vazhnoye zveno sovremennogo rasteniyevodstva [Adaptive plant protection an important link in the modern plant growing]. Zashchita $i$ karantin rastenii [Plant Protection and Quarantine]. 2019. № 2. - P. 3-10 (in Russian)]

8. Benjamin Bois Climate vs grapevine pests and diseases worldwide: the first results of a global survey / Benjamin Bois, S. Zito, A. Calonnec // OENO One Vol 51 No 2 (2017) Received : 22 December 2016; Accepted: 6 February 2017; Published : 15 May 2017 DOI: https://doi.org/10.20870/ oeno-one.2017.51.2.1780.

9. Талаш А. И. Защита растений винограда от болезней и вредителей: монография / А. И. Талаш. - Краснодар: ФГБНУ СКЗНИИСиВ, 2015. - С. 52-53.

[Talash A. I. Zashchita rastenii vinograda ot boleznei $i$ vreditelei: monografiya [Grapevine plant protection against diseases and pests. Monograph]. Krasnodar: FGBNU SKZNIISiV, 2015. - P. 52-53. (in Russian)]

10. Алейникова Н.В., Галкина Е.С., Радионовская Я.Э. Болезни и вредители виноградной лозы. Научно-практическое издание / Санкт-Петербург, 2018. - 152 с.

[Aleinikova N.V., Galkina Ye.S., Radionovskaya YA.E. Bolezni i vrediteli vinogradnoi lozy [Vine diseases and pests]. Nauchno-prakticheskoye izdaniye [Scientific and practical publication] Sankt-Peterburg, 2018. - 152 p. (in Russian)]

11. Алейникова Н.В., Якушина Н.А., Галкина Е.С. Потери урожая винограда в зависимости от эффективности защитных мероприятий // Виноградарство и виноделие: Сб. науч. тр. НИВиВ «Магарач». - Ялта. - 2013. - Т. XLIII. - C. 35-38.

[Aleinikova N.V., Yakushina N.A., Galkina Ye.S. Poteri urozhaya vinograda $v$ zavisimosti ot effektivnosti zashchitnyh meropriyatii [Losses of grape yields as a function of the effectiveness of protection measures]. Vinogradarstvo $i$ vinodeliye: Sb. nauch. tr. NIViV Magarach [Viticulture and winemaking] Yalta. - 2013. - V. XLIII. - P. 35-38. (in Russian)]

12. Calonnec, A. Effects of Uncinulanecator on the yield and quality of grapes (Vitis vinifera) and wine / A.Calonnec et al. // Plant Pathology. - 2004. - Vol. 53, Issue 4. - P. 434-445.

13. Gessler, C., Pertot, I. and Perazzolli, M. (2011) Plasmoparaviticola: a review of knowledge on downy 
mildew of grapevine and effective disease management. Phytopathologia Mediterranea, 50, 3-44.

14. Алейникова Н.В. Особенности развития основных заболеваний винограда в предгорном Крыму / Н.В. Алейникова // «Магарач». Виноградарство и виноделие. - 2007. - № 2. - C. 9-11

[Aleinikova N.V. Osobennosti razvitiya osnovnyh zabolevanii vinograda v predgornom Krymu [Peculiarities of development of major diseases of grapevine in the premountainous area of the Crimea]. Magarach. Vinogradarstvo $i$ vinodeliye [Magarach.Viticulture and Winemaking]. - 2007. - № 2. - P. 9-11 (in Russian)]

15. Якушина Н.А Влияние абиотических факторов на развитие оидиума винограда в условиях Южного берега Крыма / Н.А. Якушина, Е.С. Галкина // Виноградарство и виноделие: Сб.науч. трудов. - 2010. - Т. 40. - С. 47-49.

[Yakushina N.A, Galkina Ye.S. Vliyaniye abioticheskih faktorov na razvitiye oidiuma vinograda $v$ usloviyah Yuzhnogo berega Kryma [The effects of abiotic environmental factors on the development of oidium on grapes under conditions of the south coast of the Crimea] Vinogradarstvo $i$ vinodeliye [Viticulture and Winemaking]. 2010. - V. 40. - P. 47-49. (in Russian)]

16. Галкина Е. С. Особенности развития комплекса фитопатогенов виноградной лозы на юге Украины в меняющихся условиях среды и экологизация систем защитных мероприятий / Е. С. Галкина, Н. В. Алейникова, Н. А. Якушина // Повышение устойчивости многолетних агроценозов на основе экологизации систем защиты от вредных организмов: матер. Науч.-практ. форума. «Роль экологизации и биологизации в повышении эффективности производства плодовых культур, винограда и продуктов их переработки». - Краснодар: ГНУ СКЗНИИСиВ, 2013. - Т. 2. - С. 135-146.

[Galkina YE.S., Aleinikova N. V. , Yakushina N. A. Osobennosti razvitiya kompleksa fitopatogenov vinogradnoi lozy na yuge Ukrainy $v$ menyayushchihsya usloviyah sredy i ekologizatsiya sistem zashchitnyh meropriyatii [The features of development of vine phytopatogen complex in the south of Ukraine under changing environmental conditions and ecologization of protective system]. Povysheniye ustoichivosti mnogoletnih agrotsenozov na osnove ekologizatsii sistem zashchity ot vrednyh organizmov: mater. nauch.-prakt. Foruma. «Rol' ekologizatsii i biologizatsii $v$ povyshenii effektivnosti proizvodstva plodovyh kul'tur, vinograda $i$ produktov ih pererabotki» [Improving the sustainability of perennial agrocenoses on the basis of greening protection systems from pests: mater. Scientific Pract. forum. 'The role of greening and biologization in increasing the efficiency of production of fruit crops, grapes and their processed products'] Krasnodar: GNU SKZNIISiV, 2013. - V. 2. - P. 135-146. (in Russian)]

17. Gadoury David M. Grapevine powdery mildew (Erysiphe necator): a fascinating system for the study of the biology, ecology and epidemiology of an obligate biotroph / David M. Gadoury et al. Molecular Plant Pathology. - 2012. - 13(1). C. $1-16$

18. Fathi, H. Study of biology and epidemiology of Uncinulanecator caused powdery mildew disease / H.Fathi, H. Khiavi. Karbalaei. Technical Journal of Engineering and Applied Sciences. - 2012. - 2 (3). - C. 56-61.
19. Nujoud Alimad 1Walid Naffaa 2Fawaz Azmeh 3 Overwintering form of Erysiphe necator, the causal agent of grapevine powdery mildew in southern Syria//Journal of Plant Protection Research 2017;57(2):129-135 DOI:https://doi. org/10.1515/jppr-2017-0017.

20. Holb I. J. Monitoring of ascospore density of Erysiphe necator in the air in relation to weather factors and powdery mildew development, I. J. Holb, I. Füzi, European Journal of Plant Pathology. - 2016. - Vol. 144, Issue 4. - P. 751-762.

21. Юрченко, Е. Г. Изучение микопатосистем многолетних агроценозов на основе биоценотического методологического подхода / Е. Г. Юрченко, Г. В. Якуба, И. Г. Мищенко, Н. А. Холод, А. И. Насонов, Н. В. Савчук // Научные труды СКФНЦСВВ. - 2018. - Т. 15. - C. 79-84. DOI 10.30679/2587-9847-2018-15-79-84

Yurchenko Ye. G., Yakuba G. V. , Mishchenko I. G., Holod N. A., Nasonov A. I., Savchuk N. V. Izucheniye mikopatosistem mnogoletnih agrotsenozov na osnove biotsenoticheskogo metodologicheskogo podhoda [The study of mycopathogenic systems of multi-year agrocenoces using biocenotic methodological approach]. Nauchnyye trudy SKFNTSSVV [Scientific works of SKFNTSSVV] - 2018. - V. 15. - P. 79-84. DOI 10.30679/2587-9847-2018-15-79-84 (in Russian)]

22. Алейникова Н.В. Прогнозирование милдью на винограде / Н.В. Алейникова // Карантин і захист рослин , 2008. - № 2. - C. $20-22$

[Aleinikova N.V. Prognozirovaniye mild'yu na vinograde [Mildew forecast on vines]. Karantin i zahist roslin [Plant Protection and Quarantine] 2008. - № 2. - P. 20-22 (in Ukr)]

23. Francislene Angelotti Climate change and the occurrence of downy mildew in Braziliangrapevines / Francislene Angelotti, Emília Hamada, Edineide Elisa Magalhães, Raquel Ghini, Lucasda Ressureição Garridoand Mário José PedroJúnior // Pesq. agropec. bras., Brasília, v.52, n.6, p.426-434, jun. 2017 DOI: 10.1590/S0100-204X2017000600006

24. Caffi T. Effect of temperature and wetness duration on infection by Plasmopara viticola and on post-inoculation efficacy of copper / T. Caffi, S. E. Legler, E. GonzálezDomínguez, V. Rossi // EuropeanJournalofPlantPathology. 2016. - Vol. 144, Issue 4. - P. 737-750.

25. Методические указания по государственным испытаниям фунгицидов, антибиотиков и протравителей семян сельскохозяйственных культур / под. ред. К. В. Новожилова. - М.: Колос, 1985. - 89 с.

Metodicheskiye ukazaniya po gosudarstvennym ispytaniyam fungitsidov, antibiotikov i protravitelei semyan sel'skohozyaistvennyh kul'tur [Procedural guidelines for official tests of fungicides, anti-biotics and seed disinfectants of crops/ Ed. by K. V. Novozhilova. - M.: Kolos, 1985. - 89 p. (in Russian)]

26. Методические указания по регистрационным испытаниям фунгицидов в сельском хозяйстве / под. ред. В. И. Долженко. - С.-Пб., 2009. - 378 с.

[Metodicheskiye ukazaniya po registratsionnym ispytaniyam fungitsidov $v$ sel'skom hozyaistve [Procedural guidelines for fungicide registration tests in agriculture]. Ed. by V. I. Dolzhenko. S.-Pb., 2009. 378 p. (in Russian)]

\section{ORCID ID:}

Галкина E.C. https://orcid.org/ 0000-0003-4322-4074 Алейникова H.B. https://orcid.org/0000-0003-1167-6076 